\title{
LIFELONG LEARNING: PRACTICAL AND THEORETICAL APPROACHES TO DEVELOPING EDUCATION AND TRAINING FOR ADULTS
}

\section{НАВЧАННЯ ПРОТЯГОМ ЖИТТЯ: ПРАКТИЧНІ ТА ТЕОРЕТИЧНІ ПІДХОДИ ДО РОЗВИТКУ ОСВІТИ ТА НАВЧАННЯ ДОРОСЛИХ}

\begin{abstract}
The article deals with basic principles of lifelong learning that affect the main directions of modernization of higher educational system nowadays. Advantages and disadvantages of lifelong learning are presented. Main features of lifelong learning are shown. The concept of lifelong learning as a special form of learning, its history and development, as well as the structure and role in the contemporary circumstances of education, are highlighted. Forms, components and effectiveness of lifelong learning are identified. Analysis of world experience in integrating lifelong learning into the process of education is pointed out. The system of lifelong learning, its characteristics from the point of view of cognitive psychology and social learning studies is described. Basic motivation factors affecting the usefulness of lifelong learning are analyzed. The history of lifelong learning as a democratic, simple and free learning system is described. The attempts to identify basic features that are peculiar to adult learners are focused on. The evaluation of some general perspectives of lifelong learning applied to both adolescents and adults is underlined. Lifelong learning at higher educational establishments as a form of self-study, which takes place with constant high-quality tutorial support is examined. Basic theories relevant to do the instruction to some degree based on either a behaviorist, cognitive or social development perspective are offered. The Model of Strategic Learning in LLL is identified. Lifelong learning as one of the means that makes it possible to obtain unremitting education both in the country and abroad is characterized. Important skills that can assist lifelong learners to improve their learning experiences and understand the essence of lifelong learning are distinguished.

Key words: lifelong learning, contemporary system of education, the Model of Strategic Learning, unremitting education, motivation factors, self-direction of learners.
\end{abstract}

Стаття присвячена основним принципам навчання протягом усього життя, які впливають на основні напрями модернізації системи вищої освіти в наш час. Надано харак- теристику переваг та недоліків навчання протягом усього життя. Показано основні особливості навчання протягом усього життя. Висвітлено поняття «навчання протягом усього життя» як особливо форми навчання, його історії та розвитку, а також структуру та роль у сучасних умовах освіти. Визначено форми, компоненти та ефективність навчання протягом усього життя. Запропоновано аналіз світового досвіду інтеграції навчання протягом усього життя в процес навчання. Описано систему навчання протягом усього життя, його характеристики з точки зору когнітивної психології та соціального навчання. Проаналізовано основні мотиваційні фрактори, що впливають на ефективність навчання протягом усього життя. Описана історія навчання протягом усього життя як демократичної, простої та вільної системи навчання. Зосереджено увагу на спробах визначення основних рис дорослих учнів. Підкреслено оцінку деяких загальних перспектив навчання протягом усього життя, що застосовуються як до підлітків, так і до дорослих. Розглянуто навчання впродовж усього життя як форму самостійного навчання, що здійснюється за постійної якісної підтримки закладу освіти. Запропоновано основні теорії, які пов'язані з навчальною діяльністю та базуються на поведінковій, когнітивній чи сочіальній перспективах розвитку. Визначено модель стратегічного навчання в рамках навчання протягом усього життя. Надано характеристику навчанню впродовж життя як одного із засобів, що дає змогу здобути безперервну освіту як в межах країни, так і за ії межами. Окреслено важливі навички, що можуть допомогти учням, які навчаються впродовж життя, покращити свій досвід навчання та зрозуміти його сутність.

Ключові слова: навчання протягом усього життя, сучасна система освіти, модель стратегічного навчання, безперервна освіта, фрактори мотивації, самоспрямованість учнів.
Problem setting. Nowadays there is a tendency to enhance the role of education in the life of each individual and of humanity as a whole. This is due to the need for new knowledge, skills, which would make the process of adapting a person to the contemporary conditions more efficient and effective. The idea of education as a relatively short period of life, carried out within the rigid framework of a practically closed system, has become outdated. The limited and insufficiently effective use of forms and types of lifelong learning becomes obvious. Today, the learning process is the result of the interaction of five basic elements, namely: the learner, the teacher, content, methods and forms, sources and means of instruction, where the leading role belongs to the active components, such as, the learner and the teacher. The development of the modern education system involves openness and freedom of choice. Free education as one of the basic forms of lifelong learning implies a high level of independence and the leading role of the learner's personality; providing students with vocational education institutions with a wide range of educational services that are adequate to the demands of the regional labor market; variability of teaching methods and forms; the active use of distance learning as one of the most convenient learning methods. The technology of lifelong learning is a system of scientifically based principles of adult 
education, used to implement a high degree of guarantee that helps to achieve the educational goal [1].

Analysis of recent research and publications. Lifelong learning (LLL) is a relatively new object of research that has been investigated and characterized by numerous scientists in the sphere of adult education. The research in this field focuses on the works of such LLL theorists as Malcolm Knowles, R.M. Smith, Jack Mezirow, S.B. Merriam, Lindeman Eduard C., Stephen Brookfield and others. In their papers the researchers, notably Malcolm Knowles and K. Patricia Cross, stress that most principles of LLL derived from studies of children and adolescents can also be applied to adults.

In 1984, Knowles suggested 4 principles that are applied to adult learning, namely:

1. Adults need to be involved in the planning and evaluation of their instruction.

2. Experience (including mistakes) provides the basis for the learning activities.

3. Adults are most interested in learning subjects that have immediate relevance and impact to their job or personal life.

4. Adult learning is problem-centered rather than content-oriented [2].

Thus, Cross presents the Characteristics of Adults as Learners (CAL) model in the context of her analysis of lifelong learning programs. She underlines that the CAL model consists of two classes of variables: personal characteristics and situational characteristics. Personal characteristics include: aging, life phases, and developmental stages. These three dimensions have different characteristics as far as lifelong learning is concerned. Aging results in the deterioration of certain sensory-motor abilities (e.g., eyesight, hearing, reaction time) while intelligence abilities (e.g., decision-making skills, reasoning, vocabulary) tend to improve. Life phases and developmental stages (e.g., marriage, job changes, retirement) involve a series of plateaus and transitions which may or may not be directly related to age [3].

Many research findings from cognitive psychology and social learning studies done with adolescents are undoubtedly connected with to the development of learning experiences for adults. Still, the publications of LLL investigators make a convincing case that those who design adult learning environments should consider both general principles of learning that apply to learners of any age and those factors said to be unique or especially applicable to adult learners.

Setting objectives. The purpose of this article is to define fundamental concepts, theoretical and practical application of lifelong learning, its effectiveness, forms and models, pedagogical and psychological characteristics, motives to use, advantages and disadvantages of implementation in educational process in the system of higher education.
To investigate the main features of LLL it is essential to present brief characteristics of the adult learners. On a global scale, adult learners are those, who have passed adolescence, including professional and graduate school students, including those ones who have just started their careers and the elderly. Both theorists and practitioners in the field of LLL have made attempts to identify basic features that are peculiar to adult learners, and also some have evaluated the results of this effort, others try to ensure that such adult learner characteristics do exist.

So, four such essential characteristics can be distinguished, namely:

1) prior knowledge and experience;

2) self-directed learners;

3) critical reflection;

4) experiential learners.

Speaking about the principles of adult learning, it is worth pointing out that most adult educators have at least a degree, but a majority of them have never had any classes or training in adult education. Much attention should be given to the principles of adult learning, because they are intended to give new teachers a foundation about lifelong learning theory.

It should be stressed that the major concern is the evaluation of some general perspectives on learning that apply to both adolescents and adults, distinguishing main factors that can be used to lifelong learners in particular, and investigating certain terms that motivate adult learners. Speaking about adult motivation factors, one should point out, that various factors may motivate adult learners. Personal advancement, self-esteem, professional development and pleasure are adult motivators. Well-designed aids that consider these motivating factors are surely to be popular. However, some social factors, such as making new friends, establishing new relationships and enhancing one's ability to serve society, can also be basic key motivators. Learning for the sake of learning and developing a sense of self-efficiency are other motivating characteristics for many adults. A search for stimulating and escaping from existing routines both at home and work may serve as crucial motivating factors for some learners [4].

Although dozens of theories relevant to do the instruction to some degree have been offered, when classified in accordance with psychological backgrounds, most appear to be based in either a behaviorist, cognitive or social development perspective, namely:

- Curriculum development and lesson planning (general);

- Observe and work with the experienced teacher $\backslash$ mentor;

- Professional development options;

- Theory of how adults learn;

- Overview of LLL - funding streams, policies and procedures, program collaborations, current trends; 
- Information on teaching special populations (English as a Second Language, culturally different, learning disabled);

- Strategies to foster interaction with other teachers and service providers.

Special attention should be given to the problem of how to plan and implement instruction for adult learners. Teaching adults requires a different conceptualization and preparation than teaching children. Adults require different treatment and consideration when education and training programs are being developed. The focus of adult learning needs is centered on personal, employment, and community contexts. As stated by Dirkx and Prenger, "in contextual learning, desired competencies or skills in academic subjects, work, or parenting are integrated with specific life contexts. This means that when developing education and training, it is important not lose sight that new skills and competencies must include applicability to the learners' life needs which include family, work, and future plans. Included is an emphasis on the acquisition of important skills such as problem solving, critical thinking, and learning-to-learn as well as basic competencies related to the lesson at hand. These include: creativity, teamwork, brainstorming, problem solving, critical thinking, learning to learn skills, interpersonal communications [5].

The next basic principle to teaching adults is that each learner has extensive life experience to draw upon which allows open dialogue with the instructor about the topic at hand. Based on his or her experience, the acquisition of new skills, knowledge and abilities will be in relation to the experience levels of the individual [6].

Taking into account the behaviorist component of lifelong education, it should be mentioned that learning involves a relatively permanent change in behavior or in the potential of behavioral change resulting from experience and cannot be attributed to temporary body states such as those induced by illness, fatigue, or drugs [7].

Learning can be thought of as a process by which behavior changes as a result of experiences [8]. Learning involves change and is concerned with the accumulation of habits, knowledge, and attitudes. Learning allows the individual to make both personal and social adjustments. Any change in behavior implies that learning has taken place [9]. Learning is reflected by a change in an individual's behavior as the result of some experience.

Another important problem that should be undoubtedly mentioned is the Model of Strategic Learning in LLL. Basically, it is a framework that was developed by Weinstein (1994). The goal of the model is to assist LLL educators to gain the useful skills which will help pre-prepared learners to enhance their learning experiences and understand the importance of becoming lifelong learners. The concepts of skill will and self-regulation are also considered to be the ones that must be taken into consideration in the framework of Strategic Learning in LLL. It should be noted that LLL theories are based on the belief that adults have had different experiences in comparison with children and adolescents and that these differences are relevant to developing perfect learning conditions for adults. Moreover, while age is one of the principle factors, that can influence learning, motivation, prior knowledge, the learning context and the effect of situational and social terms are others [10].

Conclusions. This paper has investigated that the worth of lifelong learning theory rests in its capability to represent the learning process and capacity to give direction to research that, with the help of its outcomes, can develop the system of instruction.

The evidence from this study suggests that methodological approaches used in lifelong learning have their own peculiarities in comparison with teaching children. It makes the background of lifelong learning. The findings of this study indicate that teachers who carry out postgraduate training for adults must know the essential characteristics of LLL and take into consideration both theoretical and practical results of the research work connected with the process of adult instruction.

In general, these results would seem to suggest that when designing the educational process for lifelong learners of different ages, different cultures and levels of education, adult trainers they must take into account not only the psychological features of the trained adult learners and their professional needs but also be capable to imply modern methods and technologies of instruction.

The perception of educational material by adults is different than that of schoolchildren and students. Therefore, the methods used to educate children are not always effective in organizing adult education. Adults need to be taught differently.

Moreover, adult instructors should also remember that lifelong learners often do not have positive motivation to learn and learn by virtue of necessity or changing life circumstances. For most of them, learning by itself is not a welcome goal.

As a rule, adult learners are interested in studying. So, if the teacher is lucky to develop interest in the subject, to present the instruction as a useful tool at just at the beginning of the learning process, and also to ensure the learners to have a low risk, he or she can persuade adult students to learn in the necessity of gaining knowledge. This study has determined positive and negative expectations of lifelong learners can clarify the situation and increase their motivation and active participation in the learning process.

Adult students require to be taught so that they know how to act, how to solve or consider specific problems, how to use their knowledge in everyday 
professional experience, i.e. they need practice and updated material.

Lifelong learning is a democratic process where students are responsible for their own education, the outcomes of learning mostly depends on the personal characteristics of the teacher, his training background and philosophy, knowledge of the inner features of adults, the implication of teaching methods which are applied in the learning process.

\section{REFERENCES:}

1. Романцов М.Г., Мельникова ИЮ., Даниленкова Г.Г., Ледванов М.Ю., Бизенкова М.Н. Новые педагогические парадигмы, вопросы дидактики и компетентность. Академия Естествознания. 2012. С. 15-20.

2. Kearsley G. From the theory into practice. 2010. URL: http://tip.psychology.org.

3. Cross P. Adults as Learners. San Francisco: Jossey-Bass, 1981.P. 7-11.
4. Agboola O. Motivating Factors for Adult Learners in Higher Education. International Journal of Higher Education. 2015. V.4. № 1. P. 22-37.

5.Weinstein C.E. Strategic learning/strategic teaching: flip sides of a coin. Hillsdale, NJ : Lawrence Erlbaum. 1994. P. 257-273.

6. Dirkx, J.M., Prenger S.M. Planning and Implementing Instruction for Adults. San Francisco : Jossey-Bass Publishers. (1997). P. 14-27.

7.Knowles M. The Modern Practice of Adult Education: An Autobiographical Journey. New York : Association Press. (1970). P. 30-39.

8.Hergenhahn B.R. An Introduction to Theories of Learning. Englewood Cliffs, N.J. : Prentice-Hall. 1988. P. 22-26.

9. Maples M.F., Webster J.M. Thorndike's connectionism. Itasca, III.: Peacock. (1980). P. 6-18.

10. Crow L., Crow A. Readings in Human Learning. New York : McKay. 1963. P. 15-22. 